\title{
Фильтрационные параметры, характеризующие гидродинамический режим подземного выщелачивания металлов
}

Головач К.А., аспирант, Технический институт (филиал) Северо-Восточного федерального университета, 2. Нерюнгри

E-mail: aspirant.golovach@mail.ru

Научный руководитель: д.m.н., профессор Гриб Н.Н.

Практика отработки месторождений подземным выщелачиванием свидетельствует, что наиболее рентабельной и эффективной является технология выщелачивания в естественном залегании без предварительного их разрушения. Создаваемый при этом фильтрационный режим выщелачивающих растворов обеспечивает максимальный контакт их с рудной минерализацией и оптимальные условия для формирования продуктивных растворов.

С целью достижения наиболее приемлемых величин технологических показателей выщелачивания - время отработки, коэффициент извлечения металлов в раствор, отношение жидкого к твердому, расход выщелачивающего реагента (реагентоемкость пород), концентрация полезных компонентов в продуктивном растворе, необходимо учитывать фильтрационные показатели, основными из которых являются: коэффициент фильтрации, приемистость технологических скважин, скорость фильтрации растворов и возникающие при этом фильтрационные сопротивления.

Для выявления и оценки фильтрационных параметров, интервалов пород с максимальными значениями полезных компонентов и обоснования геотехнологической схемы, нами проведены аналитические расчеты по аналогии и с использованием зависимостей, полученных в ходе экспериментальных работ[1]

Использование зависимостей, обосновывается тем, что продуктивная толща пород сложена аналогичными литотипами и их физико-механические свойства различаются не значительно.

Экспериментальные работы проводились в скважинах опытного блока, пробуренных в борту карьера, которые располагались по трем параллельным рядам, рис.1, глубина бурения 22м, расстояния между скважинами 2м.

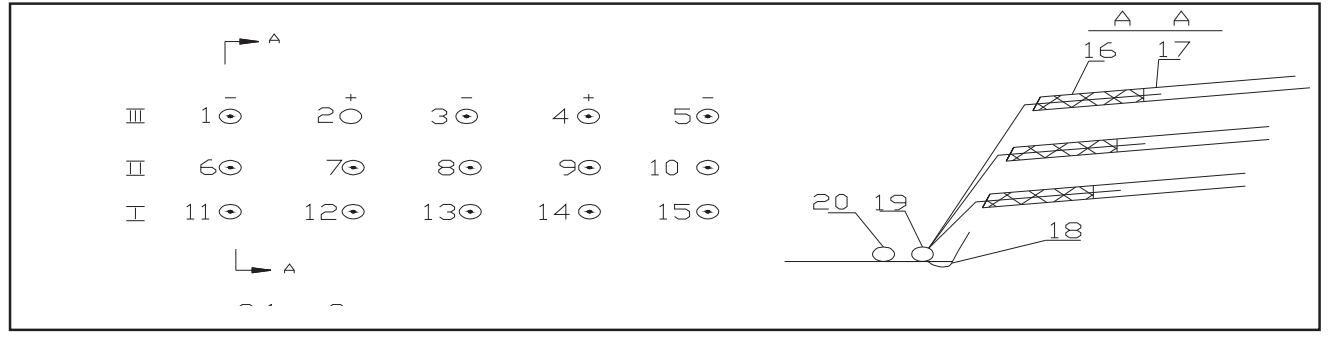

Рис. 1. Схема размещения технологических скважин в опытном блоке подземного выщелачивания

Примечание: I-III -литологические разности пород; 10- технологические скважины; 1 - номер скважины; «+» - нагнетательные скважины; «-» - разгрузочные скважины; 16 - цементная 
пробка (паккер); 17 - поэлетеленовый шланг; 18 - дренажная установка; 19, 20 - коллектор для сбора (подачи) раствора.

Устья скважин оборудовались запорными устройствами (паккерами) в виде цементных пробок длиной 2,0 м, внутри которых размещались полиэтиленовые шланги, для подачи воды и растворов выщелачивания.

Минерализованные породы на опытном участке представлены следующими литологическими разностями: алевролиты (нижний слой), слабоглинистые мелкозернистые песчаники (средний слой), глинистые среднезернистые песчаники (верхний слой). Во всех трех слоях прослеживается ярко выраженная трещиноватость, наибольшая интенсивность которой наблюдалась в алевролитах.

Нагнетание технической воды проводилось непрерывно при трех ступенях давления Р-0,2; 0,4 и 0,6 МПа.

Результаты нагнетания воды в скважины опытного блока представлены и зависимости приемистости скважин (Q) от давления нагнетания (Р) на графике, рис. 2.

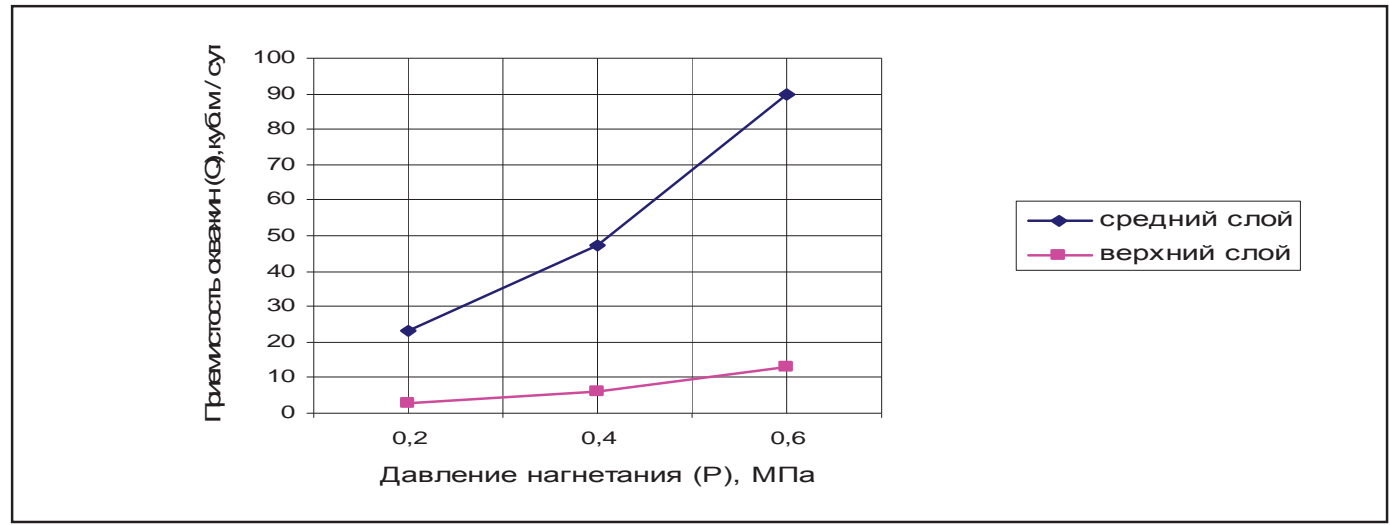

Рис. 2. Изменение приемистости (Q) скважин от давления нагнетания (Р)

В начальной стадии эксперимента проводились кратковременные нагнетания воды в каждую скважину, до достижения квазистационарного режима фильтрации, для определения исходных значений коэффициентов фильтрации.

Получены следующие значения коэффициентов фильтрации, усредненные для каждой литологической разности:

-глинистые среднезернистые песчаники - 0,5- $10^{-2}$ м / сут;

-слабоглинистые мелкозернистые песчаники - 4,0 • $10^{-2}$ м / сут;

-алевролиты - 0,2 -10

Так как породы разбиты системой мелких трещин, то коллекторские свойства массива необходимо оценивать как среду с двойной пористостью, фильтрация в которой происходит как по порам и капиллярам, так и по трещинам. Следовательно, полученные значения $K_{\phi}$ являются усредненными для трещинной и поровой фильтрации

Все это в комплексе определяет необходимость создания гидродинамического режима равномерной порово-трещинной фильтрации выщелачивающих растворов.

В нагнетательные скважины верхнего и нижнего ряда производилось попеременное нагнетание воды под давлением 0,2 и 0,4 МПа, нагнетание проводилось до установления стационарного режима фильтрации, контролируемого по объемам дренажа воды, который устанавливался, соответственно, через 8 и 12 суток непрерывной подачи воды. 
После прекращения нагнетания воды через каждые 30 сек фиксировался расход, дренирующий из скважин. Результаты наблюдений приведены на графиках, рис.3

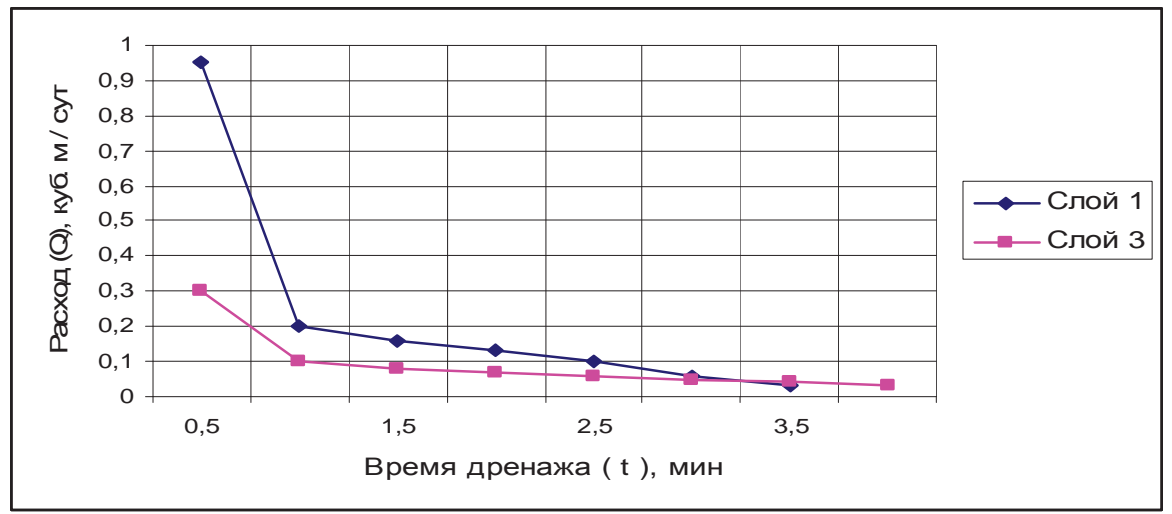

Рис. 3. Зависимость величины дренажа воды от времени, после прекращения подачи воды

На графиках отчетливо прослеживаются две области, соответствующие различным режимам фильтрации. Левая - наиболее крутая ветвь графика, линейная зависимость, соответствует области трещинной фильтрации. Правая - более пологая, также линейная зависимость, соответствует области поровой фильтрации. При прекращении подачи воды, в начальный период времени (более короткий), происходит дренаж из трещин, а затем дренируют поры и капилляры (процесс более длительный). Причем режимы поровой фильтрации для двух слоев практически идентичны, что свидетельствует об относительном равенстве их фильтрационных показателей. Исследуемые слои различаются лишь интенсивностью трещиноватости (количеством трещин на единицу объема горной массы), что отмечается при визуальном исследовании кернового материала.

Как указывалось выше, график зависимости $\mathrm{Q}^{=} \mathrm{f}(\mathrm{t})$, рис.3, соответствующий нижнему слою (алевролитам) построен для давления нагнетания 0,4МПа.

Так как крутизна отрезка прямой, характеризующей снижение интенсивности дренажа жидкости из скважины, находится в пропорциональной зависимости от степени трещиноватости породного массива, то, сравнив отношение тангенсов углов наклона отрезков прямых, соответствующих породам определенной литологической разности, получим, что степень трещиноватости верхнего слоя в 5 раз превышает соответствующий показатель нижнего слоя.

Определено, что количество жидкости фильтруемой по трещинам превышает количество жидкости фильтруемой через поры в 8,5 раз для верхнего и в 5 раз для нижнего слоя.

Полученные значения показателей соответствуют условиям формирования равномерной порово-трещенной фильтрации для пород с фильтрационной анизотропией не более одного порядка [2, 3].

Процесс подземного выщелачивания руд в фильтрационном режиме во многом определяется качеством работы нагнетательных скважин, которые должны обеспечивать необходимый расчетный уровень гидродинамического режима. Однако, практика подземного выщелачивания свидетельствует, что процессы химической и физической кольматации порово-трещинного объема пород обеспечивают условия для закономерного снижения приемистости нагнетательных систем. На рис. 4 приведены зависимости изменения приемистости скважин 2 и 9 [1] времени при подаче в породный массив кислых рабочих растворов. Обе кривые приведены к давлению в системе нагнетания 0,4 МПа. 
Процессы кольматации порово-трещиннои среды породного массива привели к снижению проницаемости верхнего и среднего слоев в 2,1 раза. Таким образом равномерное снижение приемистости анизотропных по проницаемости слоев можно объяснить, в основном, кольматацией трещинной среды тонкими пелитовыми частицами глинистых минералов [4].

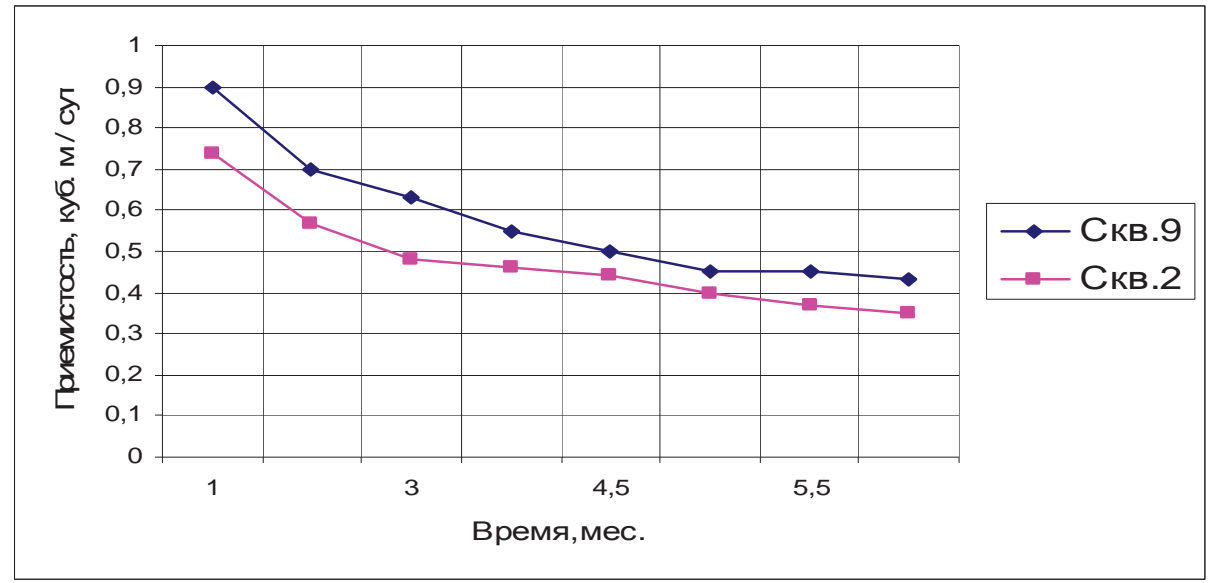

Рис. 4. Снижение приемистости нагнетательных скважин во времени

Для выявления факторов, позволяющих эффективно проводить раскольматацию порово-трещинной фильтрационной среды породного массива, проводился эксперимент по подаче рабочих растворов в режиме периодического изменения давления нагнетания. Через каждые 2 часа давление нагнетания увеличивалось на 0,2 МПа в режиме - 0,2 - 0,4 - 0,6 - 0,4 - 0,2 и т. д. Величины удельной приемистости скважин (q) оценивались за полный цикл смены давления нагнетания от 0,2 через 0,6 до 0,2 МПа за каждые 10 часов подачи растворов, в сравнении с постоянным давлением.

Таким образом, применение сменного режима подачи растворов уменьшает интенсивность снижения приемистости нагнетательных скважин, так как в результате быстрой смены гидравлических градиентов фильтрации, нарушается достигнутое равновесие между скоростью фильтрации растворов и относительной неподвижностью тонких частиц, что приводит к перемещению их и к частичной раскольматации поровотрещинной коллекторской среды и обеспечивает выравнивание скоростей движения жидкости [4].

В теории и практике гидродинамики подземных вод доказано, что при одновременной работе створа (ряда) нагнетательных скважин между ними формируются застойные «мертвые» зоны, в которых практически отсутствует движение жидкости. Образование таких зон обусловлено искривлением части радиальных потоков, движущихся от скважин во встречном направлении. Чтобы исключить влияние застойных зон на формирование дополнительных фильтрационных сопротивлений и с целью повышения приемистости скважин ,необходимо реализовать конструкцию нагнетательных и дренажных сетей в виде щелей. Сооружение таких щелей выполнено с применением гидротехнологии с использованием гидромонитора со сменными насадками.

Список литературы:

1. Ивченко С.Н. Обоснование геотехнологии комплексного извлечения полезных компонентов из налегающих пород Нерюнгринского угольного разреза // Диссертация на соискание ученой степени к.т.н. М., 2006. 
2. Веригин Н.Н. Методы определения фильтрационных свойств горных пород. М., 1962.

3. Осмоловский И.С., Маркелов С.В., Лобанов П.Д. Комплекс исследований по оценке параметров процесса подземного выщелачивания металлов. М., 1984.

4. Осмоловский И.С., Маркелов С.В., Лобанов П.Д. О повышении раствороприемности нагнетательных и дренажных скважин при выщелачивании руд в блоках. М., 1984.

\section{Перевод легковых автомобилей на газовое топливо в Олекминском районе}

Горбунова В.В., студентка, Северо-Восточный федеральный университет, 2. Якутск

E-mail: iqevika78@mail.ru

Научный руководитель: стариий преподаватель Егорова Е.Н.

Легковой автомобиль на газе, сегодня, безусловно, можно встретить гораздо реже, чем транспортное средство, использующее в качестве топлива только бензин или дизель. Учитывая растущие цены на бензин и другие нефтепродукты, в настоящее время об установке газобаллонного оборудования (ГБО) начинают задумываться даже те, кто несколько лет назад о подобном и не задумывался. В настоящее время число автовладельцев, желающих перейти на менее дешевое моторное топливо увеличивается в геометрической прогрессии. Это, во-первых, связано с экономической обстановкой в стране и в мире в целом, а во-вторых с предъявляемыми экологическими нормами.

В данной работе рассмотрена возможность перевода легковых автомобилей на газовое топливо в Олекминском районе.

По данным ГИБДД Олекминского района, на 20.10.2016 г в Олекминском районе имеется 3498 легковых автомобилей разного года выпуска. Основная часть автовладельцев использует в качестве топлива бензин - Аи-92, Аи-95, и лишь малая часть автомобилей заправляется дизельным топливом. В таблице 1 и 2 приведены количественный состав импортных и отечественных автомобилей.

Таблица 1

Количественный состав импортных автомобилей в Олекминском районе по годам выпуска

\begin{tabular}{|c|c|c|}
\hline № & Год выпуска автомобилей & Количество \\
\hline 1 & До 1990 г. & 87 \\
\hline 2 & $1991-1995$ гг. & 360 \\
\hline 3 & $1996-2000$ гг. & 870 \\
\hline 4 & $2001-2005$ гг. & 1130 \\
\hline 5 & $2006-2010$ гг. & 477 \\
\hline 6 & $2010-2015$ гг. & 270 \\
\hline 7 & 2016 и выше & 5 \\
\hline 8 & Итого & 3199 \\
\hline
\end{tabular}

